Article

\title{
Resisting Perceived Interference in Journalistic Autonomy: The Study of Public Service Media in Slovakia
}

\author{
Marína Urbániková \\ Department of Media Studies and Journalism, Masaryk University, Czech Republic; E-Mail: urbaniko@fss.muni.cz
}

Submitted: 18 February 2021 | Accepted: 12 April 2021 | Published: 21 October 2021

\begin{abstract}
Autonomy is of paramount importance for journalism, but there is little empirically based knowledge of how journalists cope when it is threatened. Using a case study approach, this contribution examines a newsroom conflict that took place in the public service Radio and Television of Slovakia. It started when the new director general, a person believed to have ties to one of the coalition political parties, was elected by the parliament in 2017, and it culminated in layoffs and resignations of more than 30 reporters and editors in 2018. The case study is based on semi-structured interviews $(N=16)$ with the journalists who decided to quit in protest of what they called "creeping political pressure," those whose contracts were not prolonged, those who decided to stay at their jobs, and the members of the previous and the new management. Building on the interviews and document analysis, the article inductively develops a classification scheme for resistance practices the journalists used to cope with the perceived interference with their professional autonomy that came from within their media organisation. These practices include having internal discussions, voicing concerns during newsroom meetings, writing an internal letter to the management, meeting with the management, establishing a trade union, requesting mediation, writing an open letter to the viewers and listeners, publicly criticising the management in the media, voluntarily asking to be re-assigned to another topic area or position in order to avoid interference, staying at one's job in open opposition to the management, and resigning in protest.
\end{abstract}

\section{Keywords}

autonomy; interference; newsroom conflict; pressure; public service media; resistance practices; RTVS; Slovakia

\section{Issue}

This article is part of the issue "Media Control Revisited: Challenges, Bottom-Up Resistance and Agency in the Digital Age" edited by Olga Dovbysh (University of Helsinki, Finland) and Esther Somfalvy (University of Bremen, Germany).

(C) 2021 by the author; licensee Cogitatio (Lisbon, Portugal). This article is licensed under a Creative Commons Attribution 4.0 International License (CC BY).

\section{Introduction}

Professional autonomy is one of the holy grails of journalism. The freedom of journalists to make and follow their own norms and rules of practice is one of the key idealtypical values upon which journalism's ideology is based (Deuze, 2005). It is what makes journalism a profession (Freidson, 1994) or, in Bourdieu's terms, what makes it a separate field (Bourdieu \& Wacquant, 1992). Given its paramount significance, important questions arise: How do journalists react when they feel that their autonomy is threatened? What options and measures do they have to handle what they perceive as undue interference?

This study sheds more light on the different ways that professional autonomy can be defended in prac- tice. More concretely, it focuses on the resistance practices used to deal with perceived internal pressure from within the news organisation (i.e., from management). It employs a qualitative case study approach (Yin, 2018) to analyse a newsroom conflict that took place in the Slovak public service broadcaster Radio and Television of Slovakia (RTVS) in 2017 and 2018. The conflict started when the new director general, a person believed to have ties to one of the then-coalition political parties, was installed by the parliament, and it culminated with the layoffs and resignations of more than 30 reporters and editors who complained of "creeping political pressure" (Jančáriková, 2018).

Even though the importance of professional autonomy in journalism is well documented in the scholarly 
literature, resistance practices used by journalists when their autonomy is in jeopardy have rarely been studied (as pointed out, e.g., by Barrios \& Miller, 2020). Empirical studies mostly focus on the perceived level of journalistic autonomy in various countries (Ahva et al., 2017; Hughes et al., 2017), or, from the opposite angle, on exploring various types and forms of interference in journalistic autonomy (Akhrarkhodjaeva, 2017b; Goyanes \& Rodríguez-Castro, 2019) and on the extent of the journalists' experience with this interference (Clark \& Grech, 2017; Hiltunen, 2019). However, the question of how journalists actually deal with the pressure and interference is less often addressed, and if so, available studies have focused mostly on external political interference that occurs in flawed democracies and authoritarian or hybrid regimes (Ataman \& Çoban, 2019; Barrios \& Miller, 2020; Slavtcheva-Petkova, 2019). Another relevant stream of literature, the research on conflicts in public service media, zeroes in on cultural clashes between the content makers and top managers who are responsible for administering and running "the factory" (Nissen, 2014), and on concrete cases when the independence of public service broadcasters was breached and journalistic autonomy constrained (Dragomir, 2017; Dzięciołowski, 2017; Koivunen, 2017). Again, an emphasis on the array of possible resistance practices of dissatisfied journalists is missing. This is where this study steps in.

The case of the newsroom conflict in the public service medium in Slovakia is of interest for three reasons. First, as already suggested, previous research has focused primarily on external political interference in non-democratic countries, unlike this study, which examines the case of (perceived) internal interference from within the media organisation in a European Union country with a relatively high ranking for democracy and press freedom. Slovakia is currently ranked 42nd out of 167 countries in the 2019 Democracy Index (The Economist Intelligence Unit, 2020), and 33rd out of 180 countries in the 2020 World Press Freedom Index (Reporters Without Borders, 2020). Second, this study contributes to our knowledge of journalism culture in Central and Eastern Europe, a region which has, compared to Western societies, been studied considerably less (e.g., Standaert et al., 2019). As journalistic autonomy certainly did not belong to the core ideal-typical values of journalism during the communist times, the question arises whether and to what extent the journalists working for the public service broadcaster in Slovakia adopted autonomy as an essential value that was worth defending. And third, journalistic autonomy is of particular importance in the realm of public service media because their raison d'être is independence from both political and economic pressure. Therefore, although journalists in general are expected to defend their autonomy when they feel it is under attack, this expectation is reasonably higher in the case of journalists working for public service media, which makes RTVS an interesting case to study.
This article is organised as follows: It first reviews the literature on the resistance practices that journalists use to cope with interference in their autonomy and, drawing from organisational studies, reviews the literature on the practices that employees use to express their dissent (Section 2); it describes the research method and data (Section 3); it analyses the newsroom conflict and introduces an inductively developed classification scheme of resistance practices through 16 semistructured interviews with the journalists and managers from the RTVS newsroom (Section 4); Section 5 is the summary and conclusion.

\section{Literature Review: Resisting Interference and Voicing Dissatisfaction}

\subsection{Journalistic Autonomy and Coping With its Encroachment}

Journalistic autonomy is the "latitude that a practitioner has in carrying out his or her occupational duties" (Weaver et al., 2007, p. 70). It refers to "the extent to which journalists can make decisions free of pressures from management, commercial factors, as well as other forces that reside inside the news environment" (Reich \& Hanitzsch, 2013, p. 135). Journalistic autonomy can be threatened by the interference of various actors, either internally, from within the journalistic field (e.g., editors, managers), or externally, most notably from the political or economic fields. Interference can be described as threats or inducements which cause or attempt to cause journalists to act in a particular fashion (Hanretty, 2011, p. 5), or as methods used to "influence journalists with the objective of shaping editorial content" (Hiltunen, 2019 , p. 5). Thus, interference does not only refer to direct interventions (or attempts at interventions) in the journalistic content, but also to all sorts of pressure to discipline the journalists and make them act according to the interests of the sources of this pressure. In the case of internal actors (most notably editors), in order to qualify their actions as interference, these actions must be journalistically unwarranted.

Available studies that explore the practices used by journalists when they feel their autonomy is endangered focus mostly on cases of external political interference that occur in flawed democracies and authoritarian or hybrid regimes (see Ataman \& Çoban, 2019, for Turkey; Barrios \& Miller, 2020, for Columbia; Fedirko, 2020, for Ukraine; Slavtcheva-Petkova, 2019, for Russia). These practices include: seeking support from editors (Barrios \& Miller, 2020; Slavtcheva-Petkova, 2019); sharing or handing over sensitive stories to other colleagues or working anonymously (Ataman \& Çoban, 2019; Barrios \& Miller, 2020); using social media to attract followers in order to raise the costs for the potential sources of the pressure (Barrios \& Miller, 2020); trying to solve the problems by directly contacting the sources of the pressure (Slavtcheva-Petkova, 2019); practicing borderless 
and cross-border journalism (Ataman \& Çoban, 2019); and using the support of international actors (Ataman \& Çoban, 2019; Barrios \& Miller, 2020).

Studies that focus on democratic countries mostly examine how journalists deal with commercial interference, either internal or external (see Borden, 2000, for the U.S.; Goyanes \& Rodríguez-Castro, 2019, for Spain; Hanusch et al., 2017, for Australia and Germany). Regarding external commercial interference, coping practices include avoiding negative accounts about a product or service (Goyanes \& Rodríguez-Castro, 2019; Hanusch et al., 2017); not reporting about a product or service at all (Hanusch et al., 2017); and being more careful about meeting journalistic norms in sensitive cases (Goyanes \& Rodríguez-Castro, 2019). Regarding internal commercial pressure, according to Borden (2000), journalists use open protest, sabotage (e.g., making decisions without consulting higher levels of management), principled compromise (i.e., concession in order to accomplish basic journalistic goals), and "trump cards," which suggest that non-compliance with standard journalism would lead to a loss of credibility.

Although these studies provide useful insights into how journalists cope with interference in different contexts, none of them examine a situation similar to this case study: A case of perceived internal interference that comes from within the media organisation and that is interpreted by dissenting journalists as the lack of professional skills on the side of the management (in the best case) and as politically motivated (in the worst case). Thus, this case study explores a unique situation where journalists perceive the interference of their superiors as journalistically unwarranted with only speculation for the underlying motivations.

\subsection{Employee Dissatisfaction in an Organisation: Exit and Voice in Journalism}

Besides research that focuses on how journalists deal with perceived encroachment on their autonomy, organisational studies are the second relevant stream of scholarship upon which this contribution is based. Specifically, it builds up the literature on the practices that employees use to express their dissent for the organisation where they work. In his widely cited work, Hirschman (1970) summarised that people respond to the decline in the performance of organisations mainly by exit or voice. They either leave the organisation (or stop buying its products), or they voice their discontent and exert pressure upon the organisation to improve its performance. Loyalty is the key moderating variable: Less loyal employees and customers are more likely to exit; more loyal ones are more likely to use their voice (Hirschman, 1970). Later research identified a variety of other predictors such as: organisational commitment; job satisfaction; perceived justice, trust, and fairness; psychological contract violation; job alternatives; employability; and psychological safety (Aravopoulou et al., 2017; Subhakaran \& Dyaram, 2018).
Farrell (1983) enriched the exit-voice conceptualisation with two other options. Besides quitting or voicing their discontent, dissatisfied employees can opt for loyalty (i.e., stick with the organisation and patiently wait for improvement) or neglect (i.e., passive behaviour, withdrawal, and hostility). Focusing on employees' voice strategies, Gorden (1988) distinguished four types that are based on active-passive and constructive-destructive dimensions. Accordingly, as summarized by Kassing (2002), employees' voice can be active constructive (e.g. making suggestions, argument, union bargaining), passive constructive (e.g., listening, quiet support, unobtrusive compliance), active destructive (e.g., complaining, ingratiation, verbal aggression, antagonistic exit), or passive destructive (e.g., murmurings, apathy, withdrawal).

In the field of journalism and media studies, the exitvoice-loyalty-neglect model has been applied for several purposes: to explore and evaluate journalist resistance to business constraints (Borden, 2000); to analyse the responses of journalists to ethical dilemmas (Saldaña et al., 2016); or to examine career choices of journalists (Akhrarkhodjaeva, 2017a; Davidson \& Meyers, 2016). Arguably, media organisations have several specific features that need to be taken into account when applying the exit-voice-loyalty-neglect model to journalists' behaviour. These traits make journalists' position when it comes to expressing dissent different from that of, for example, assembly line workers. Journalism is a specific profession with a high potential for conflict and employee dissatisfaction. The very nature of journalism - the construction of media representations of reality-offers much room for ideological tensions. Also, journalism can be considered as a semi-profession (Tunstall, 1971) without universally accepted standards and rules of practice and without a clear definition of what good professional performance is. This can be another source of potential disputes between journalists and management.

Journalism entails not only a high risk of conflicts but also specific requirements for their resolution. When journalists disagree with their employer's editorial policy, the stakes are high, and so are the societal demands placed on them. It is in journalists' vital interest to defend their autonomy as, without it, they lose their authority and can no longer be considered professionals (Borden, 2000). However, at the same time, journalists who would openly voice their discontent face extremely high costs (Borden, 2000). In some cases, using voice may mean quitting with "the possible prospects of not being able to return to the profession until conditions change" (Akhrarkhodjaeva, 2017a, p. 8). Also, many journalists hold the view that those who disagree with the editorial policy of their media organisation are free to quit and change to another one (Schimpfossl \& Yablokov, 2014). In short, it seems that in journalism, there is an increased pressure on journalists to opt for voice or exit as opposed to loyalty or neglect-and of course, that comes with a price. 


\section{Data and Method}

This article aims to explore the resistance practices used by the journalists working for RTVS to cope with what they perceived as the undue interference of their superiors upon their professional autonomy during a newsroom conflict that took place in 2017 and 2018. The study asks not only what resistance practices the journalists used, but also what was their order, and how was the selection of individual practices related to the broader journalists' strategies of how to respond to the unsatisfactory conditions in the newsroom. Even though the conflict affected both the radio and television divisions of RTVS, this study focuses on the television only because the clash was more dramatic, more closely followed by the public, and led to more staff resignations.

As a broader methodological strategy to learn more about the journalistic resistance practices, a case study approach-“an empirical method that investigates a contemporary phenomenon (the 'case') in-depth and within its real-world context" (Yin, 2018, p. 15)-was employed. Conflicts where journalists publicly complain of interference with their autonomy serve as a useful research opportunity because they allow for the capture of the variability of individual and collective resistance practices, as well as the sequences. To explore the case of RTVS, I conducted 16 semi-structured interviews with the main actors of the conflict (e.g., journalists, managers) and supplemented it with document analysis (e.g., news articles, an open letter written by journalists, the management's response) as a form of triangulation.

As pointed out by Nissen (2016), conflicting parties in public service media organisations typically offer different interpretations of what happened. What one stakeholder describes as a brave defence of autonomy and independence, another interprets as a consequence of unsatisfactory performance and a lack of loyalty. Obviously, semi-structured interviews cannot reveal which side of the conflict in RTVS was "right" or "wrong," nor do they prove whether or to what extent the new RTVS management interfered with the professional autonomy of the journalists. However, this methodological approach can shed more light on how the journalists reacted once they perceived the interference. To verify (to the extent possible) the basic facts, I checked for inconsistencies in the versions and interpretations of conflicting parties and compared them with descriptions of individual events as captured in the news and other documents. All the interviewees agreed on the elementary explanation of what happened, and the document analysis also supported these findings. As expected, what was not agreed upon were individual actors' motivations and the interpretation of key values that needed to be protected.

Given that the subject of the analysis is an organizational conflict, it is essential to mention the RTVS' internal structure. RTVS was created in 2011 following a merger of Slovak Television with Slovak Radio, and the director general supervises both the radio and television divisions. They are elected (and potentially also dismissed) by a simple majority of votes in the parliament. The term of office is for five years, and the same person may be elected to only two consecutive terms. When it comes to news making, the highest-ranking role (right below the director general) is the head of television and radio news and current affairs. Their direct subordinates are the editor-in-chief of television news and current affairs and the editor-in-chief of radio news and current affairs. One level below the editors-in-chief are the team leaders who lead the rank-and-file reporters.

The selection of conversational partners was led by an effort to cover the key groups of actors and to maximise the diversity in the sample from the viewpoint of position, gender, age, and length of working experience. Participants were selected based on the author's knowledge of the case. With one exception, none of the addressed participants declined the invitation to participate in the research study. The conversational partners fall into five key groups: the journalists whose contracts were not prolonged by the new management ( 1 participant); the journalists who resigned in protest (4); the journalists who decided to stay at their jobs (5; however, one of them resigned shortly after the interview); newly appointed managers (4); and members of the previous management who resigned (2). Managers are defined as people who oversaw editors and rank-and-file reporters (e.g., team leaders, the head of television and radio news and current affairs). The years of experience of the 5 female and 11 male participants ranged from 3 years to more than 20. In the following text, for the sake of brevity, I use the umbrella term "journalists" to denote the dissenting part of the newsroom that included a major part, though not all, of the reporters and editors.

The interviews were carried out between July 2018 and September 2019. All of the interviews were recorded, anonymised, transcribed verbatim, and subjected to coding in Atlas.ti. To ensure better anonymity for the conversational partners, the generic feminine pronoun is used throughout the text when referring to the participants. To analyse the data, I used thematic analysis, "a method for identifying, analysing and reporting patterns (themes) within data" (Braun \& Clarke, 2006, p. 79). The coding and analysis process followed the analytic procedure suggested by Braun and Clarke (2006): It started with familiarising with the data and generating initial codes, continued with searching for themes (collating the codes in potential themes) and reviewing themes (including the creation of a thematic map), and ended with defining and naming themes, and producing the report.

\section{Analysis: The Many Shades of Resistance}

In what follows, I analytically describe the newsroom clash in RTVS which resulted in a significant staff turnover. Based on the interviews and the document analysis, I inductively developed a classification scheme (Marradi, 
1990) for the resistance practices used by the journalists. They can be divided into two groups (Figure 1): resistance when a change within the organisation is deemed possible, and resistance when change within the organisation is no longer deemed possible. Another dividing line establishes resistance practices that can be either internal (i.e., intra-organisational) or external (i.e., extra-organisational). The dissatisfied journalists at first believed that change was possible and, as a general rule, although with some exceptions, they first used internal resistance practices, then they resorted to externalresistance practices. These practices did not lead to change, so the journalists eventually accepted the status quo and opted for resistance practices based on personal reactions to the unsatisfactory situation. Although Figure 1 suggests a general direction of individual steps, the process is reiterative rather than linear (e.g., requesting a meeting with the management was a step that was taken repeatedly in several stages of the conflict).

\subsection{Prelude and Exposition: The Election of a New Director General}

The prelude to the newsroom conflict at RTVS started with the election of the new director general. In a secret ballot in June 2017, the Slovak parliament chose Jaroslav Rezník to take the top position at RTVS. This choice was received with apprehension by part of the journalistic community and the public for two reasons. First, in the months preceding the election, the two leading politicians, then-Prime Minister Robert Fico (the chairman of Smer-SD party) and then-parliament speaker Andrej Danko (the chairman of the Slovak National Party), persistently and openly criticised RTVS and its management for being anti-Slovak, anti-government, biased, unfair with questions, and not publicising the successes of the government (e.g., Benedikovičová, 2016), and they claimed that "there must be a change in the leadership of RTVS" ("IPI criticises Slovak PM's," 2017). The second reason was personal: Jaroslav Rezník, the new director general, was believed to have ties to the Slovak National Party, the party that helped significantly to push through his nomination. Thus, the new director general took office in August 2017 in an atmosphere of tension and negative expectations.

The concerns were fuelled by the changes in the top management in September 2017. Rezník broke one of the key unwritten rules of journalism - to maintain a strict border between journalism and public relations-and appointed three former press officers

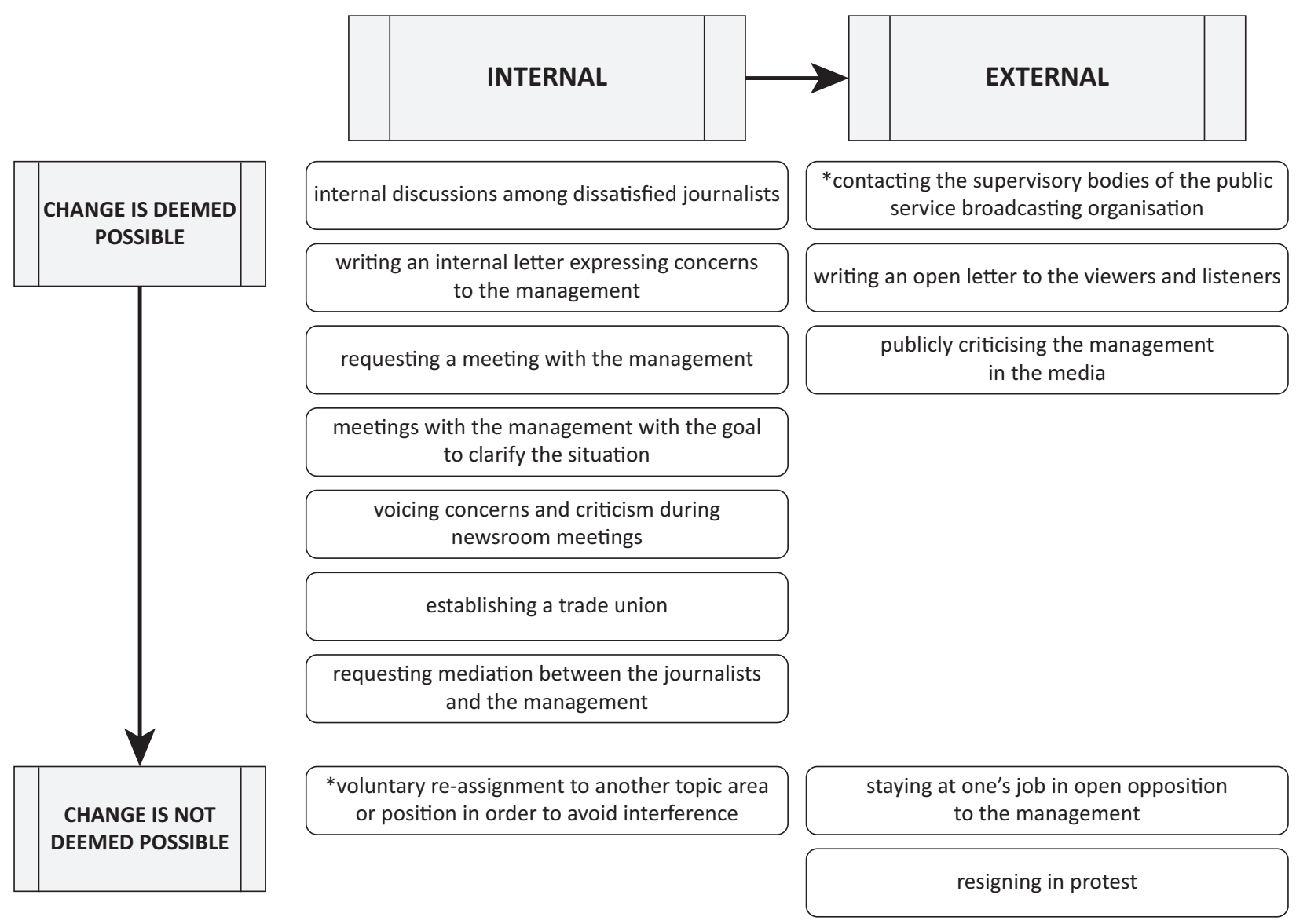

Figure 1. Resistance practices of the journalists facing internal interference with their professional autonomy. Note: The practices marked with an asterisk were mentioned by the research participants as a considered option, but they were not actually used. 
from ministries and state organisations as the new topmanagers for the television and radio newscasts. This was seen by some journalists as a conflict of interest that put RTVS' credibility in danger. The new director general refused to acknowledge the conflicts of interest and take steps to ensure that the people coming from the political environment would not have the direct control of the news content. As a consequence, the editor-in-chief resigned in protest, and the rest decided to wait and see what would come; at this stage, the concerned journalists discussed the issue internally and informally.

\subsection{Collision: A Shutdown of an Investigative Programme and an Explosive Staff Meeting}

In winter 2018, the management of RTVS decided to shut down its only investigative TV programme The Reporters (Reportéri in Slovak) without any discussion with the show's editors, ostensibly due to the lack of quality. This decision came shortly after the programme broadcast a story critical of Matica Slovenská, a state-funded national cultural organisation linked to the Slovak National Party and to Jaroslav Rezník, the director general, whose father happened to be a member of the organization's presidium. After protests from both the media community and the public, the show was reintroduced in September 2018, but the production team had been changed. Furthermore, soon after airing the Matica Slovenská story and the subsequent complaint of the organisation, RTVS broadcast what was marked by several interviewed journalists as an unusually laudatory story about the organization in its evening news programme.

The journalists tried to resolve their concerns within the organisation. They wrote an internal (non-public) letter to the management and requested a meeting for management to answer their questions:

In January, the newsroom became very concerned about this, but we talked internally that we didn't want to be hysterical and that maybe these were just communication misunderstandings that we wanted to resolve within the organisation. We wrote an internal letter signed by 77 or 78 people. [It] was a short text with these points that were very worrying....[We wrote] that we believe that it was a misunderstanding and that we were asking Director General Rezník for an immediate staff meeting to explain all of this. (Interview with an RTVS reporter, July 2018)

The staff meeting took place in January 2018 and included approximately 70 reporters from both the television and radio news divisions and the management that was supposed to calm the situation. The most noteworthy moment, according to various research participants, was a speech by one of the radio managers. Allegedly, he explained, the laudatory news story about Matica Slovenská was broadcast because, as cited by several of the interviewed reporters, "sometimes steps need to be taken to soften the impact of a complaint" (Interview with an RTVS reporter, February 2019). This was met with loud protests from the reporters-they described their reaction as shock, some of them because they found such an approach to be journalistically and morally unacceptable and others because they were surprised that he admitted it so openly. As summarized by one of the interviewed reporters, "[E]veryone was shocked that he said that out loud. Even if it does happen, one does not say it [laughter]" (Interview with an RTVS reporter, February 2019).

Soon after the meeting, two of the three new top managers (i.e., former spokespersons) decided to resign, officially for personal and health reasons. According to the interviewees, they left due to the growing tensions between the director general and the news staff in which they were caught. The tension grew when one of the vacant managerial positions-the head of television and radio news and current affairs - was taken by Vahram Chuguryan, a journalist-turned-spokesman who worked, among other things, as a spokesperson for two ministers who were nominated by the then-coalition parties. Again, his professional past raised concerns among some reporters.

\subsection{Crisis: Banned Badges, Quarrels About Objectivity, Open Letters, and Layoffs}

The conflict entered its most heated stage in the strained atmosphere that followed the murder of Ján Kuciak, an investigative journalist who was shot dead with his fiancée in their home at the end of February 2018. Vahram Chuguryan, the new top-manager, asked the television reporters not to wear badges with the portrait of the murdered couple on-screen. The badge was originally designed and produced by the publisher of the news website for which Ján Kuciak had worked, and it quickly became a symbol of solidarity with the victims and their families. The badge became popular with many of the participants of the anti-government mass protests that were sparked by the murder and that eventually led to the resignation of Prime Minister Robert Fico and his cabinet. The new top-manager considered the badge to be a political symbol. Shortly after a discussion in the newsroom, the journalists leaked the story about the "ban on badges" to their colleagues in other media. At this stage, the dissatisfied journalists started to publicly express their concerns and criticise the management.

The tension grew into an open conflict. In the interviews, both sides mentioned hostile and stressful morning editorial meetings with every day quarrels, fights, shouting, and insults. It seems that what followed was a clash of two groups with two distinct journalistic cultures and different political orientations (including foreign political orientation in terms of East vs. West). On a practical level, this led to arguments about when a balancing quote was needed, what to include as the 
"opposite" view, what sources to quote, who was a credible and relevant expert source, and how to name certain events. In short, these questions concerned objectivity, and even more broadly, they concerned the perceptions of journalistic roles and of public service. Also important to mention is that, according to some of the interviewed journalists, these clashes often had one thing in common-they were somehow related to the Slovak National Party (i.e., the party that pushed through the nomination of the director general), its leaders, and the areas of its interest.

None of the interviewed reporters mentioned any case of censorship. Nobody reported any direct command or prohibition with regard to the production of journalistic content, nor any case of an editorial change without the author's consent. However, all the reporters, regardless of whether they decided to leave RTVS, complained of pressure exerted on them or their colleagues to conform to the views of the managers and to stop challenging them. According to the interviewed reporters, punishment was meted out for failures to adjust to their managers' perception of objectivity, their notion of how to select sources, and the actors and opinions to include through two disciplinary measures: excessive negative feedback and cuts to bonuses, which were otherwise a significant part of their monthly pay.

A step that some of the journalists considered, but decided not to take, was contacting the supervisory body of RTVS-the RTVS Council. The Council oversees the functioning of RTVS, sets the salary of the director general, and it can submit a motion for filing a proposal for their dismissal to the relevant committee of the parliament. All nine council members are elected directly by the parliament. However, the interviewed journalists did not turn to the Council because they did not believe that the members were genuinely interested in discovering what was going on in the newsroom (and the members of the Council did not approach them on their own).

The journalists continued to request a meeting with the director general to describe the situation in the newsroom. However, according to the interviewed reporters, despite an initial promise made after the first big staff meeting in January, he avoided the meetings, postponed them, or cancelled one at the last minute. In this situation, in April 2018, around 60 RTVS reporters and editors signed a critical open letter to the viewers and listeners. They stated that they "continue to work freely... but in a hostile climate" and that they fight with "distrust in [their] superiors, their intentions, and their skills" ("Otvorený list," 2018). They objected to the conflicts of interest of their managers and former spokespersons, and they accused the management of suppressing critical voices. In their public response, Jaroslav Rezník and the top managers labelled the signatories as young, inexperienced, and radical. Also, in reaction to the open letter, 35 reporters, anchor-persons, and other RTVS employees signed another open letter stating that they work freely and without pressure.
Soon after, the RTVS managers ended the contracts of four reporters who were among the signatories of the critical open letter and who openly confronted and criticised their superiors during the editorial meetings. The management took advantage of the fact that, due to the lack of financial resources, several of the RTVS personnel were technically self-employed contractors, even though they were a stable and long-term part of the newsroom. Therefore, when getting rid of undesirable personnel, it was possible to cancel their contracts overnight instead of providing a much more complicated formal dismissal notice.

\subsection{Peripety: The Establishment of a Trade Union and Requests for Mediation}

In April 2018, the opposing journalists established a trade union to protect their jobs and compel management to hold a meeting. According to Slovak law, the employer is obliged to negotiate with a trade union. Moreover, it is illegal to dismiss employees' representatives during their term of office and for six months afterwards. Also, the employer may give notice or immediately terminate the employment of a member of a trade union only with the prior consent of the employee's representatives.

At the same time, there were repeated attempts at independent mediation to resolve the conflict. These attempts failed as well. Both sides of the dispute were not able to agree on the mediator: The management wanted to select the mediator and expected the journalists to accept the choice.

\subsection{Catastrophe: A Wave of Resignations}

Taking into account the aforementioned events, it came as no surprise that at the end of May 2018, 12 television reporters and editors handed in their notices of termination. Resignation in protest happened shortly after the unsuccessful negotiation between the trade union with the director general. According to one of the reporters, before the meeting they still hoped that he did not have enough information about what was going on in the newsroom: "After this meeting we understood that he knew what was going on, he knew that our letters of resignations were almost on the table, but he actually did not care" (Interview with an RTVS reporter, July 2018). Thus, the non-extension of the contracts for the four journalists, together with a (perceived) lack of interest on the part of the general director, seemed to be the turning point after which journalists stopped trying to change the conditions within the organisation and started to focus on resolving their personal situation within the status quo.

When explaining their decision, none of the reporters mentioned any experience of censorship but several of them expressed that the pressure from the new management put them at risk of self-censorship: 
The situation was terribly bad and there was enormous pressure for self-censorship. That's the main thing. No one told us what to write, but everyone, subconsciously, was already considering that I know that if I write this there, I know that they [the managers] will criticise me harshly tomorrow morning. (Interview with an RTVS reporter, February 2019)

As summarized by one of the interviewed reporters: "Censorship does not manifest itself only by someone saying that you can't broadcast something, but also by the exemplary punishing of colleagues who get bogged down in a topic that the management is not comfortable with" (Interview with an RTVS reporter, October 2018). As the reporters and editors who decided to resign explained in their public statement, they repeatedly tried to come to an agreement with the management but had now reached a point beyond which they could not go further, and that their resignation was a matter of professionalism and journalistic honour. They also declared: "We loved, love, and will love RTVS....We have children, mortgages, and obligations, but most of all-we love this job very much. Under these circumstances at RTVS, however, we cannot carry out [our work] as faithfully as before" (Spravodajské odbory RTVS, 2018). The management of RTVS stated that they regretted this decision but respected the choice of the reporters.

Besides resignation in protest, the dissatisfied journalists had two other options. One of the research participants considered voluntary re-assignment to another topic area or position in order to avoid the pressure (e.g., a transfer from the news section to the current affairs section), but in the end, she decided otherwise. Another option was to stay at one's job, but in open opposition to the management. This included open criticism both within the organisation and publicly. Some of the interviewed journalists who at some point belonged to the rebel group opted for yet another approach: They decided to focus on their own jobs and retreated into "internal exile"; however, this could be considered to be a strategy of acceptance rather than a strategy for resistance.

By Summer 2019, around two-thirds out of 26 television reporters left or were denied contract extensions. The same applies to roughly one-half of the editors and all of the on-line editors.

\section{Conclusions}

This article explored the resistance practices used by the journalists who worked for RTVS, the Slovak public service broadcaster, to cope with what they perceived as the undue and journalistically unwarranted interference of their superiors with their professional autonomy. The resistance practices identified in this case study included internal discussions among dissatisfied journalists, the writing of an internal letter to express concerns to the management, requests for a meeting with the management, meetings with the management with the goal to clarify the situation, the voicing of concerns and criticism during regular newsroom meetings, contacting supervisory bodies of the public service broadcasting organisation, the establishment of a trade union, requests for independent mediation between the journalists and the management, the writing of a public open letter to the viewers and listeners, the public expression of concerns and criticism in the media, requests for voluntary re-assignment to another topic area or position in order to avoid pressure, staying at one's job but in open opposition to the management, and resignation in protest. To summarize, the journalists gradually moved from voice to exit, indicating that-in line with past studies (Borden, 2000; Davidson \& Meyers, 2016)using voice eventually comes at extremely high costs in journalism.

These resistance practices are very different from those identified in previous research, which largely examined cases of external political interference (Ataman \& Çoban, 2019; Barrios \& Miller, 2020; SlavtchevaPetkova, 2019) or external/internal commercial interference (Borden, 2000; Goyanes \& Rodríguez-Castro, 2019; Hanusch et al., 2017). This suggests that the choice of specific types of resistance is closely related to the source and type of interference. Another important variable is the type of organisation; some of the identified resistance practices can only be used in public service media (e.g., contacting supervisory bodies of public service broadcasting organisation).

In the organisational studies literature, voice strategies are distinguished from the employer's perspective based on active-passive and constructive-destructive dimensions (Gorden, 1988). However, this study argues that professional conflicts should not be assessed solely from the standpoint of the employer. If, for instance, voice has to be used to defend professional autonomy, from the viewpoint of the journalistic profession, labelling individual strategies as constructive or destructive may look quite different. This study therefore introduces a different conceptualisation that adopts the perspective of employees, and that is based on two main dimensions, reach and aim. In terms of reach, resistance practices can be either internal (i.e., used within the organisation) or external (i.e., extending beyond the boundaries of the organisation). Also, they can aim at the improvement of the conditions within the organisation (i.e., these practices are used when journalists still believe change is possible) or they can aim at resolving the personal situation when change in the organisation is no longer considered possible. In the first stage, the dissatisfied journalists tried to improve the conditions in the organisation with internal resistance practices. As a general rule, although with some exceptions, they only resorted to external resistance practices once they had exhausted the internal ones. In the second stage, the journalists accepted the status quo and opted for resistance practices that were focused on personal reactions to the unsatisfactory status quo. The reiterative model 
of resistance practices, including the general direction of individual steps, introduced in this study can be further developed and tested in other newsroom conflicts both in public service and commercial media organisations.

Also, this case study supports Hirschman's (1970) claim that the key moderating variable that influences the response to dissatisfaction is loyalty. The journalists had long sought to change the situation in the organisation because they identified with its values and mission, felt to be a part of it, and considered the steps of the new management to be a threat to its reputation and ability to fulfil its mission. Another important variable that was identified in this case study is peer support and the journalists' ability to organise and resist collectively. Several of the resistance practices were collective (not individual), and many of the interviewed journalists mentioned that mutual support was a significant factor that helped them continue in resistance. The significance of the collective aspect of resistance must be emphasized all the more as journalists are often reluctant to organise themselves and practice their occupational voice (Davidson \& Meyers, 2016).

Finally, this case study suggests that, even though journalistic autonomy historically did not belong to the core ideal-typical values of journalism in Slovakia, a country that once belonged to the Soviet sphere of influence, a significant part of the journalists who worked at RTVS considered it to be an essential value that was worth defending, even at the cost of their jobs. This is an important finding as throughout its history, public service broadcasting in Slovakia has been repeatedly attacked and used as a political tool (most flagrantly under Prime Minister Vladimír Mečiar and his autocratic style of government in 1994-1998). In the previous cases, journalists either adapted to the new conditions or decided to leave without much struggle. This time, the dissenting journalists refused to succumb to self-censorship or to adopt the practice of "adekvatnost" (i.e., a state of being adequate) that produces journalism corresponding to the authorities' expectations (Schimpfossl \& Yablokov, 2014), which is known from contemporary Russia. Thus, even if some scholars argue that, in countries where the development of journalism culture has been disrupted, including Slovakia, journalistic autonomy is less deeply rooted in professional ideology or not regarded as important at all (Lauk \& Harro-Loit, 2016), the conflict at RTVS signals that a non-negligible part of Slovak journalists abandoned the Soviet model of journalism and adopted the key values of the Western journalism culture not only rhetorically but also through their actions. This is a positive signal in terms of the vitality of the journalistic profession and the strength of public service media in Slovakia and, more broadly, in the CEE region.

\section{Acknowledgments}

The author wishes to thank all the research participants for their time and insight, as well as to the issue editors and two anonymous reviewers for helpful comments on earlier draft of the manuscript.

\section{Conflict of Interests}

The author declares no conflict of interests.

\section{References}

Ahva, L., van Dalen, A., Hovden, J. F., Kolbeins, G. H., Löfgren Nilsson, M., Skovsgaard, M., \& Väliverronen, J. (2017). A welfare state of mind? Nordic journalists' conception of their role and autonomy in international context. Journalism Studies, 18(5), 595-613.

Akhrarkhodjaeva, N. (2017a). Russian media and journalists' dilemma between "exit, voice, and loyalty." Russian Analytical Digest, 197, 5-8.

Akhrarkhodjaeva, N. (2017b). The instrumentalisation of mass media in electoral authoritarian regimes: Evidence from Russia's presidential election campaigns of 2000 and 2008. ibidem-Verlag.

Aravopoulou, E., Mitsakis, F. V., \& Malone, C. H. (2017). A critical review of the exit-voice-loyalty-neglect literature: Limitations, key challenges, and directions for future research. The International Journal of Management, 6(3), 1-10.

Ataman, B., \& Çoban, B. (2019). Turkey: How to deal with threats to journalism? In E. Eide, K. Skare Orgeret, \& N. Mutluer (Eds.), Transnational otheringGlobal diversities: Media, extremism, and free expression (pp. 171-190). Nordicom.

Barrios, M. M., \& Miller, T. (2020). Voices of resilience: Colombian journalists and self-censorship in the post-conflict period. Journalism Practice. Advance online publication. https://doi.org/10.1080/17512 786.2020 .1778506

Benedikovičová, M. (2016, November 26). Sme v krčme? Dočerta, spamätajte sa, útočil Fico na moderátora, ked'sa pýtal na Lajčáka [Are we in a pub? Damn, get real, Fico attacked the moderator when he asked about Lajčák]. Denník N. https://dennikn.sk/617975/ sme-v-krcme-docerta-spamatajte-sa-utocil-fico-namoderatora-rozhlasu-ked-sa-pytal-na-lajcaka

Borden, S. L. (2000). A model for evaluating journalist resistance to business constraints. Journal of Mass Media Ethics, 15(3), 149-166.

Bourdieu, P., \& Wacquant, L. J. D. (1992). An invitation to reflexive sociology. Polity Press.

Braun, V., \& Clarke, V. (2006). Using thematic analysis in psychology. Qualitative Research in Psychology, 3(2), 77-101.

Clark, M., \& Grech, A. (2017). Journalists under pressure: Unwarranted interference, fear, and self-censorship in Europe (1st ed.). Council of Europe.

Davidson, R., \& Meyers, O. (2016). "Should I stay or should I go?": Exit, voice, and loyalty among journalists. Journalism Studies, 17(5), 590-607.

Deuze, M. (2005). What is journalism? Professional iden- 
tity and ideology of journalists reconsidered. Journalism, 6(4), 442-464.

Dragomir, M. (2017, August 29). The state of Hungarian media: Endgame. LSE Media Policy Project. https://blogs.Ise.ac.uk/medialse/2017/08/29/thestate-of-hungarian-media-endgame

Dzięciołowski, K. (2017). Is there a chance for nonpartisan media in Poland? (Reuters Institute Fellowship Paper). Reuters Institute; University of Oxford. https://reutersinstitute.politics.ox.ac.uk/sites/ default/files/2017-12/Is\%20there\%20a\%20chance\% 20for\%20non-partisan\%20media\%20in\%20Poland\% 20-\%20Krzysztof\%20Dzieciolowsk\%20Paper.pdf

Farrell, D. (1983). Exit, voice, loyalty, and neglect as responses to job dissatisfaction: A multidimensional scaling study. Academy of Management Journal, 26(4), 596-607.

Fedirko, T. (2020). Self-censorships in Ukraine: Distinguishing between the silences of television journalism. European Journal of Communication, 35(1), 12-28.

Freidson, E. (1994). Professionalism reborn: Theory, prophecy, and policy. University of Chicago Press.

Gorden, W. I. (1988). Range of employee voice. Employee Responsibilities and Rights Journal, 1(4), 283-299.

Goyanes, M., \& Rodríguez-Castro, M. (2019). Commercial pressures in Spanish newsrooms: Between love, struggle, and resistance. Journalism Studies, 20(8), 1088-1109.

Hanretty, C. (2011). Public broadcasting and political interference. Routledge.

Hanusch, F., Hanitzsch, T., \& Lauerer, C. (2017). "How much love are you going to give this brand?" Lifestyle journalists on commercial influences in their work. Journalism, 18(2), 141-158.

Hiltunen, I. (2019). Experiences of external interference among Finnish journalists. Nordicom Review, 40(1), 3-21.

Hirschman, A. O. (1970). Exit, voice, and loyalty: Responses to decline in firms, organizations, and states. Harvard University Press.

Hughes, S., Garcés, M., Márquez-Ramírez, M., \& Arroyave, J. (2017). Rethinking professional autonomy: Autonomy to develop and to publish news in Mexico and Colombia. Journalism, 18(8), 956-976.

IPI criticises Slovak PM's remarks on public broadcaster. (2017, April 12). International Press Institute. https://ipi.media/ipi-criticises-slovak-pms-remarkson-public-broadcaster

Jančáriková, T. (2018, May 31). Reporters quit Slovak public broadcaster to protest at political pressure. Reuters. https://www.reuters.com/article/usslovakia-politics-media-idUSKCN1IW25M

Kassing, J. W. (2002). Speaking up: Identifying employees' upward dissent strategies. Management Communication Quarterly, 16(2), 187-209.

Koivunen, A. (2017). \#Sipilägate and the break-up of the political bromance: Crisis in the relationship between Finnish media and politicians. Nordicom, 39(1), 44-51.

Lauk, E., \& Harro-Loit, H. (2016). Journalistic autonomy as a professional value and element of journalism culture: The European perspective. International Journal of Communication, 11, 1956-1974.

Marradi, A. (1990). Classification, typology, taxonomy. Quality and Quantity, 24(2), 129-157.

Nissen, C. S. (2014). Organisational culture and structures in public media management: In search of a model for the digital era? In M. Głowacki \& L. Jackson (Eds.), Public media management for the twentyfirst century: Creativity, innovation, and interaction (pp. 81-102). Routledge.

Nissen, C. S. (2016). Obeying his masters' voices: Managing independence and accountability in public service media between civil society and state. In G. F. Lowe \& C. Brown (Eds.), Managing media firms and industries: What's so special about media management? (pp. 121-142). Springer.

Otvorený list členov Sekcie spravodajstva a publicistiky RTVS (plné znenie) [Open letter of the members of the news and current affair section to the viewers and listeners (full text)]. (2018, April 4). SME. https://domov.sme.sk/c/20795636/otvoreny-listclenov-sekcie-spravodajstva-a-publicistiky-rtvsplne-znenie-reznik.html

Reich, Z., \& Hanitzsch, T. (2013). Determinants of journalists' professional autonomy: Individual and national level factors matter more than organizational ones. Mass Communication and Society, 16(1), 133-156.

Reporters Without Borders. (2020). Slovakia. https://rsf. org/en/slovakia

Saldaña, M., Sylvie, G., \& McGregor, S. (2016). Journalism-business tension in Swedish newsroom decision making. Journal of Media Ethics, 31(2), 100-115.

Schimpfossl, E., \& Yablokov, I. (2014). Coercion or conformism? Censorship and self-censorship among Russian media personalities and reporters in the 2010s. Demokratizatsiya: The Journal of Post-Soviet Democratization, 22(2), 295-311.

Slavtcheva-Petkova, V. (2019). Fighting Putin and the Kremlin's grip in neo-authoritarian Russia: The experience of liberal journalists. Journalism, 20(11), 1530-1546.

Spravodajské odbory RTVS [News service trade union RTVS]. (2018, May 31). Dnes, 31. mája 2018, sme sa dvanásti rozhodli podat výpovede [Today, May 31, 2018, twelve of us have decided to resign] [Facebook status update]. https://www.facebook.com/watch/ ?v=1870199999707113\&ref=sharing

Standaert, O., Hanitzsch, T., \& Dedonder, J. (2019). In their own words: A normative-empirical approach to journalistic roles around the world. Journalism. Advance online publication. https://doi.org/ 10.1177/1464884919853183

Subhakaran, S. E., \& Dyaram, L. (2018). Interpersonal 
antecedents to employee upward voice: Mediating role of psychological safety. International Journal of Productivity and Performance Management, 67(9), 1510-1525.

The Economist Intelligence Unit. (2020). Democracy index 2019: A year of democratic setbacks and popular protest. https://www.in.gr/wp-content/uploads/ 2020/01/Democracy-Index-2019.pdf

Tunstall, J. (1971). Journalists at work. Specialist corre- spondents: Their news organizations, news sources, and competitor-colleagues. Constable.

Weaver, D. H., Beam, R. A., Brownlee, B. J., Voakes, P. S., \& Wilhoit, G. C. (2007). The American journalist in the 21st century: US news people at the dawn of a new millennium. Routledge.

Yin, R. K. (2018). Case study research and applications: Design and methods (6th ed.). SAGE.

\section{About the Author}

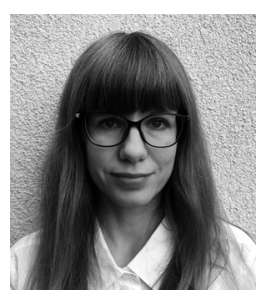

Marína Urbániková is an assistant professor at the Department of Media Studies and Journalism, Masaryk University, Czech Republic. Her research interests include topics of journalistic autonomy, journalism cultures, public service media and its independence, security and safety of journalists, journalism education, and public confidence in media and journalists. She has published, among others, in European Journal of Communication, Journalism Practice, and International Communication Gazette. 